\title{
NON GRID CONNECTED HYBRID SYSTEM USING SOLAR ETHANOL FOR RENEWABLE ENERGY PRODUCTION FOR VILLAGE SARVAR DEWLA
}

Alok Kumar Mehta ${ }^{1}$ and Prof. Preeti Gupta ${ }^{2}$

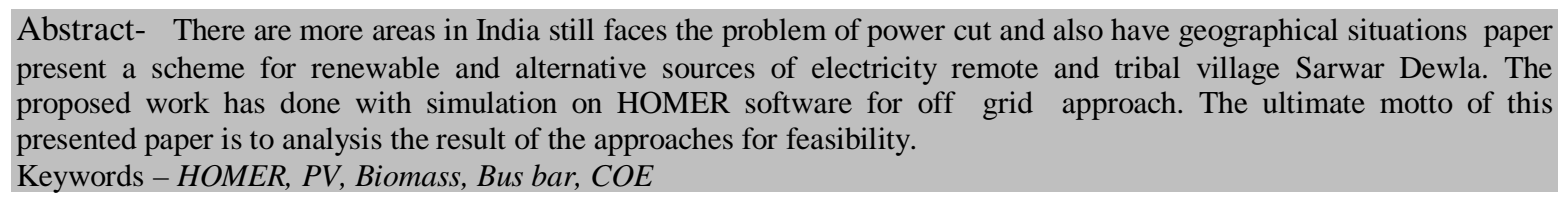
present a scheme for renewable and alternative sources of electricity remote and tribal village Sarwar Dewla. The proposed work has done with simulation on HOMER software for off grid approach. The ultimate motto of this presented paper is to analysis the result of the approaches for feasibility.

Keywords - HOMER, PV, Biomass, Bus bar, COE

\section{INTRODUCTION}

Earlier the energy need of any human society was very limited due to limited expansion of such conversion work is quite simple and limited \&its consumption was a linear process but in today's era electrical power system is one of the complex networks in the world with invention of new techniques of power generation and utilization. The HOMER software is a very fast tool for designing and analyzing hybrid power system with renewable energy sources. HOMER is a computer model that simplifies the task of designing distributed generation systems - both on and off-grid. HOMER's optimization and sensitivity analysis.

\section{Proposed System}

The proposed hybrid alternative energy system comprises of biomass generator, PV, and micro hydal. Solid State Converter is also used for conversion of its output to AC. This system is design for off grid system. Sarwar Dewla is a small tribal village located in Khargone district, Madhya Pradesh with total 1613 persons residing as per Population Census 2011. Among which approximately 500 tribal families resides for way from main village. The survey conducted in village for utilization of the electrical equipments available like TV, Fan, and Light, etc. but in the absence of power they could not used the device. The total load peak load with daily electricity consumption is shown in table 1:

\footnotetext{
${ }^{1}$ Oriental College of Technology Bhopal (M.P.) India
}

${ }^{2}$ Oriental College of Technology Bhopal (M.P.) India 
Table 1

Electric Load of Study Area Village Sarwer Dewla (M.P.)

\begin{tabular}{||c|c|c|}
\hline Load Category & Peak Load & $\begin{array}{c}\text { Daily Electricity } \\
\text { Consumption }\end{array}$ \\
\hline \hline Cottage Houses & $12 \mathrm{KW}$ & $216 \mathrm{KWH} / \mathrm{D}$ \\
\hline & & $4.6 \mathrm{MWH} / \mathrm{D}$ \\
\hline $\begin{array}{l}\text { Irigation } \\
\text { System }\end{array}$ & $200 \mathrm{KW}$ & $4.816(\mathrm{KWH} / \mathrm{Day})$ \\
\hline \multicolumn{2}{|c|}{ Total Load (KWH/Day) }
\end{tabular}

\section{NON GRID CONNECTED MODEL}

The off grid or standalone model for the above concept is designed with all three sources of electricity ethanol, PV hybrid system. The hybrid system has chosen because of Solar PV is selected as most of month availability of solar radiations while due to forest and agricultural area; agricultural wastes are available in bulk which has no use of other purpose even in some cases villagers destroy them with fire so its availability is at very low cost. Figure 2 shows the off grid model. The Village sarwar dewlap is far away from main city there is more power cut problem only 5 to 7 hours supply in a day and all time villagers suffer electricity problem. The Solar-Ethanol hybrid system is the best option for fulfill the villagers electricity need as the village is nearby sugar industry which has enough raw material available to develop a hybrid system.

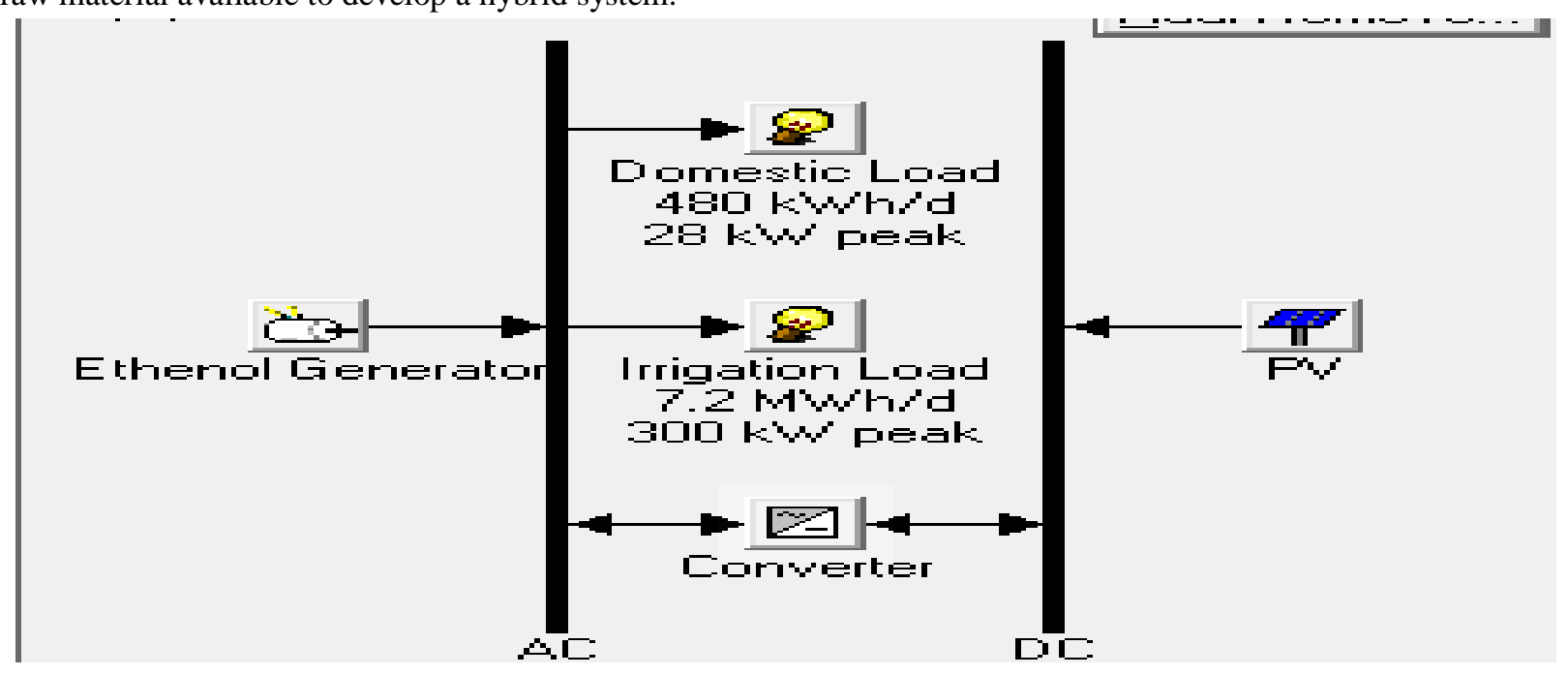

Figure 1 Off Grid Hybrid Renewable Energy System

\section{RESULT AND DISCUSSION}

The HOMER software automatic consider the different size of components for feasible model according to pre defined size by user and gives the number of simulated results in simulated results the best optimized result is shown as in fig 2 


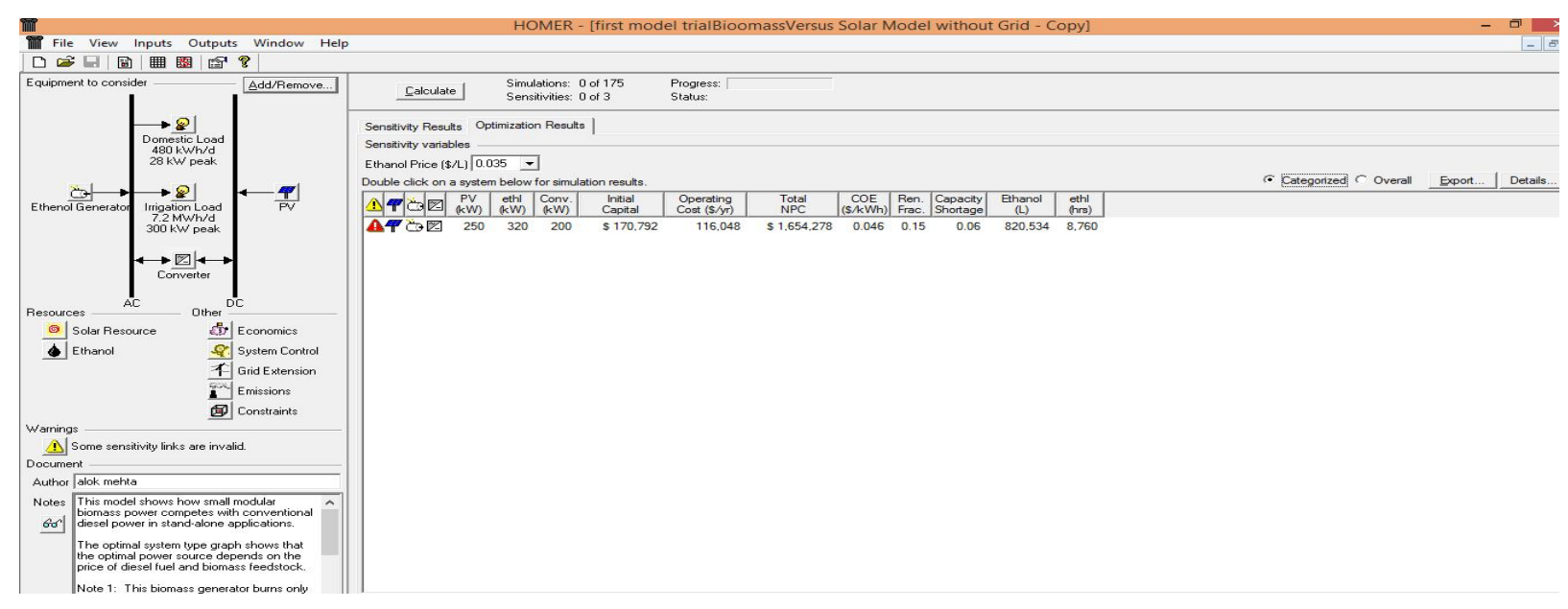

Figure 2 Optimized Result for off grid model

The total capital cost of all the components is $\$ 170792$, replacement cost after components life completed $\$ 779499$, during running time, Fuel Cost $\$ 367121$, and salvage cost \$ -22659 salvage cost mean after completed system life usable components cost. The NPC \$ 1654278 and COE have shown in table at different cost of biomass and different carbon percentage. Figure 3 shows all these details

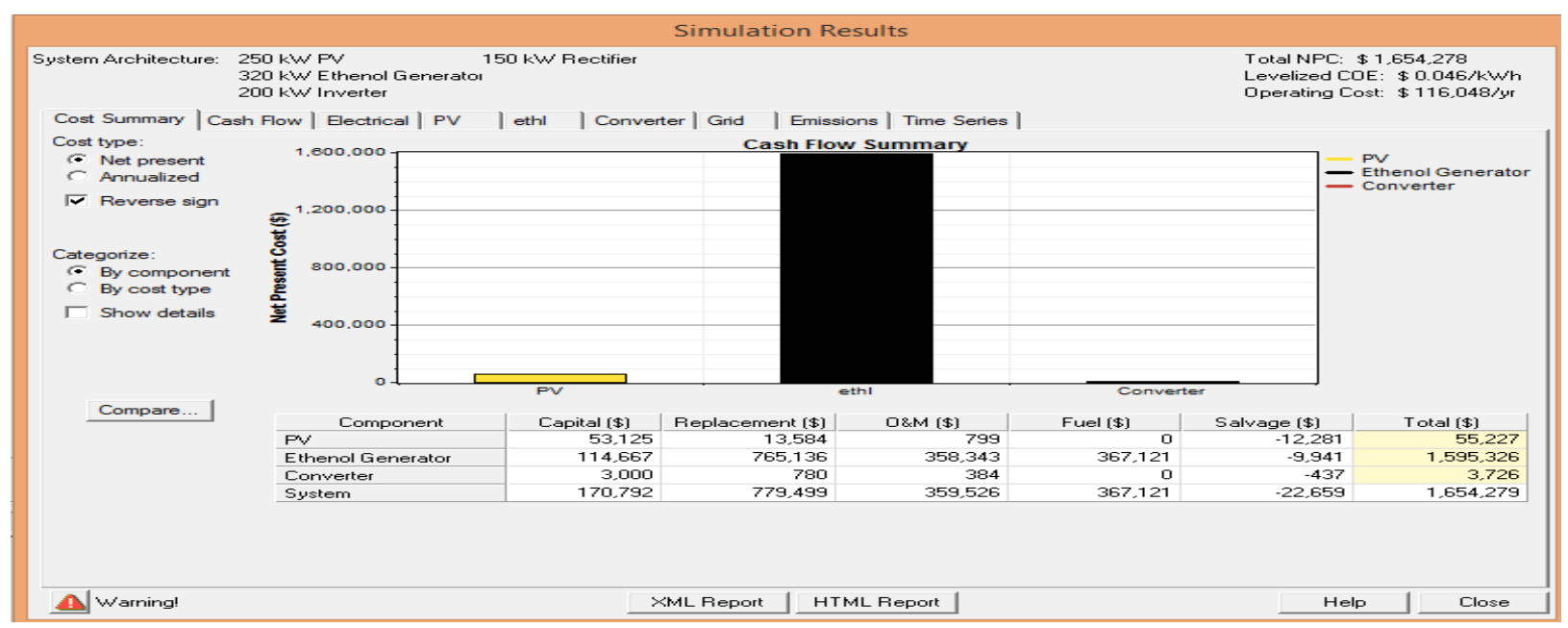

Figure 3 Cost summery for off grid system

In hybrid system architecture of hybrid system is as $250 \mathrm{KW}$ PV system, $320 \mathrm{~kW}$ Ethanol generator system, $200 \mathrm{~kW}$ Inverter are used. The cash flow chart of solar-Ethanol hybrid system show that the cost of energy per unit is reduces after first year because after installation year per year expenditure is low only fuel and operating cost invest and after 5 year replacement cost in spend. Figure 4 shows the cash flow of off grid model 


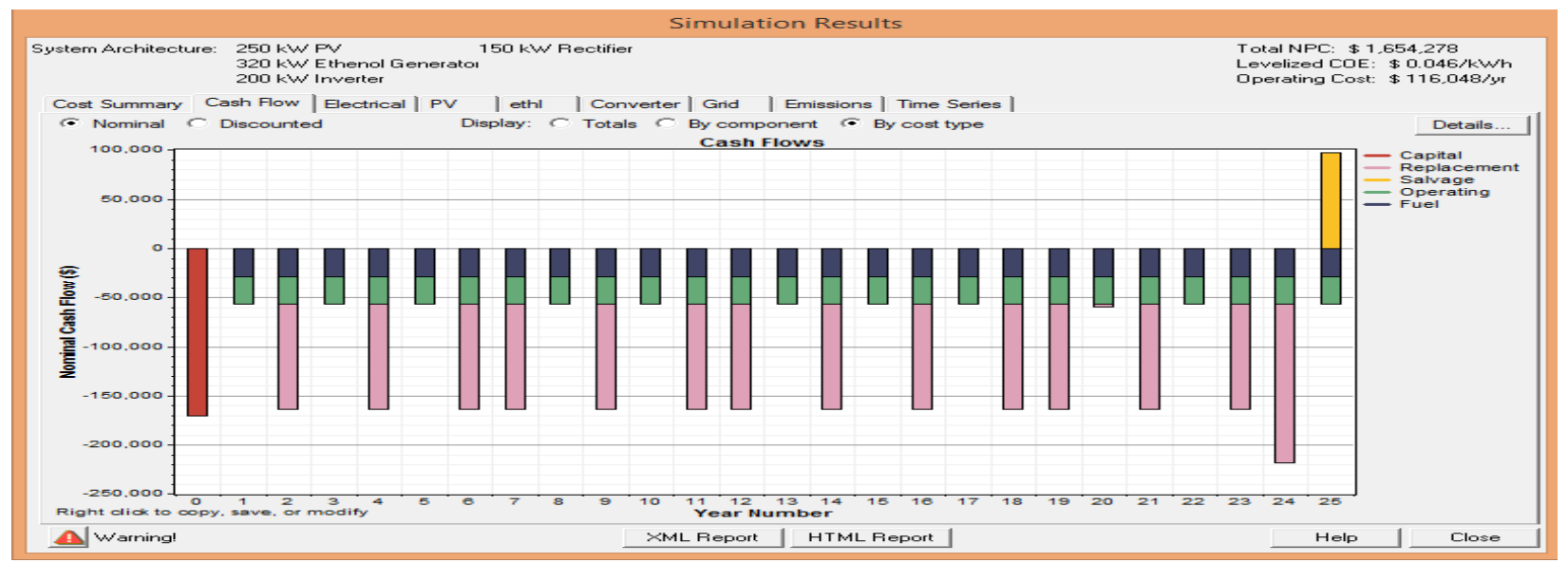

Figure 4 Cash Flow of Off grid Model

In solar-ethanol hybrid system the number of PV array are used \& ethanol generators to fulfill the electric load requirement $4.816 \mathrm{MWh} / \mathrm{d}$. The total production of power is $2305455 \mathrm{kWh} / \mathrm{yr}$, in which power $(84 \%)$ is by Ethanol generator, (16\%) by Solar PV. The bar graph show the electricity production by solar and ethanol as upper yellow color bar show the solar panels output power and lower color show the ethanol generator output. Figure 5 shows the electricity production by off grid model

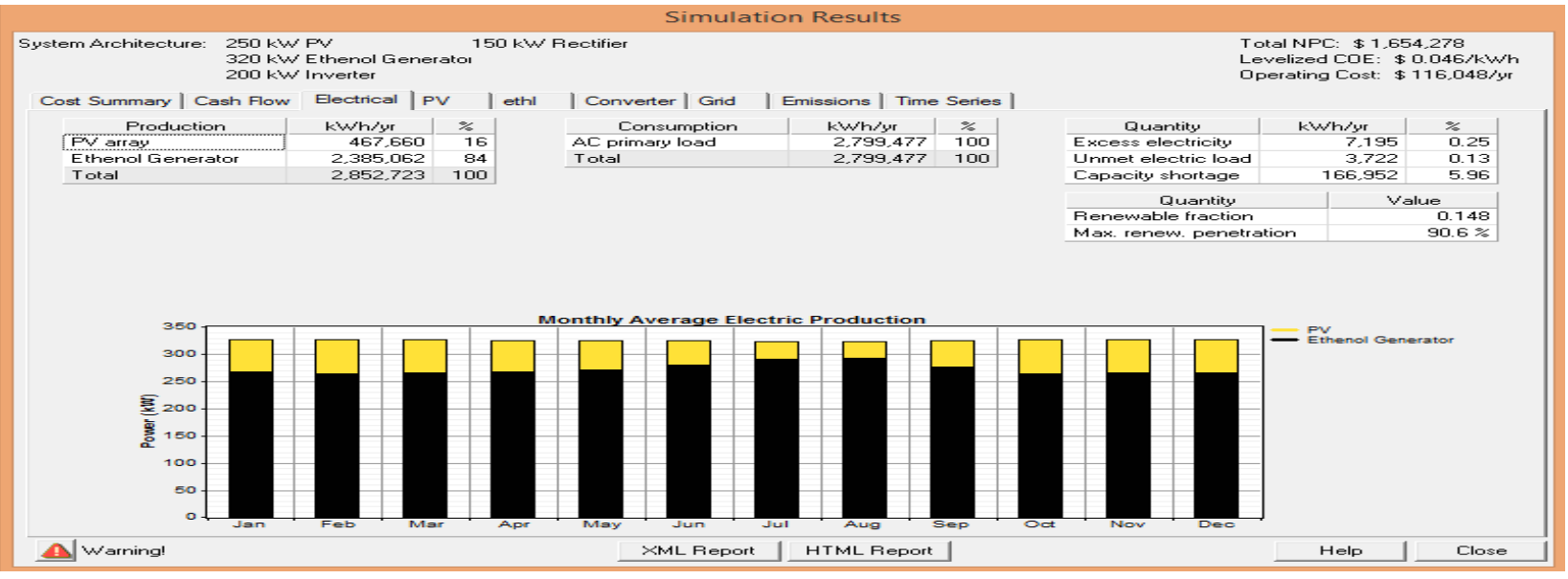

Figure 5 electricity production off grid model

Figure 6 is about PV output of off grid model

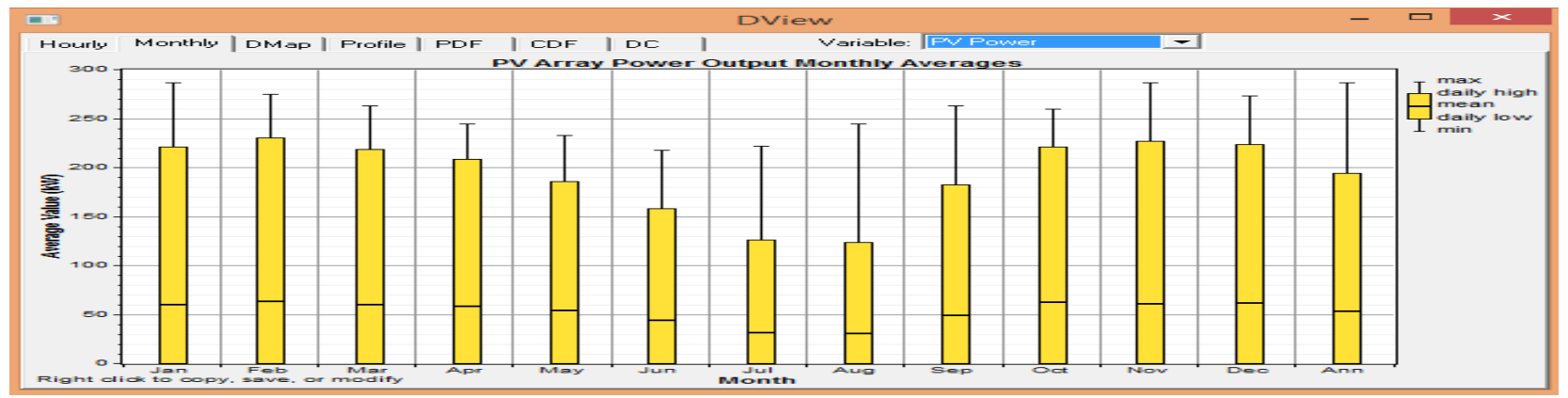

Figure 6 PV out put off grid

Figure 7 tells the Ethanol generation is for off grid model 


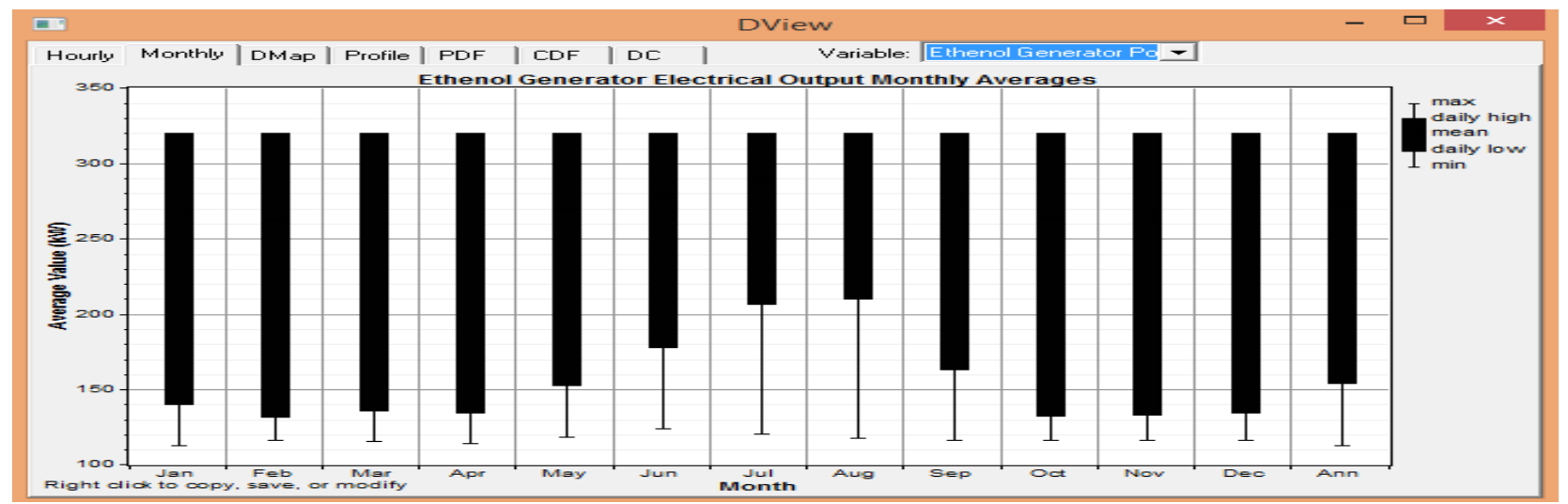

Figure 7 Ethanol Electricity generation off grid

Table 2 is discusses the COE and NPC for off grid system:

Table 2

Result of COE \& NPC

\begin{tabular}{|c|c|c|c|c|}
\hline \multirow[t]{2}{*}{ S. No } & \multirow{2}{*}{$\begin{array}{l}\text { COE/Lt } \\
\text { (In Rs.) }\end{array}$} & \multirow{2}{*}{$\begin{array}{c}\text { Carbon in } \\
\text { Ethanol } \\
\text { (In \%) }\end{array}$} & \multicolumn{2}{|c|}{ Stand Alone Model } \\
\hline & & & $\begin{array}{c}\text { COE/KWH } \\
\text { Rs.) }\end{array}$ & $\begin{array}{c}\text { NPC } \\
\text { (In Rs.) }\end{array}$ \\
\hline 1 & 2.07 & 37 & 3.105 & 110526408 \\
\hline 3 & 2.42 & 37 & 3.174 & 114145182 \\
\hline 5 & 2.76 & 37 & 3.312 & 117763956 \\
\hline
\end{tabular}

The cost data gives different rates of biomass and same carbon contain and residual flow of water. The tables gives least cost of electricity at lower biomass value and is suitable for rural purpose and gives electricity to a common men.

\section{REFERENCES}

[1] http://www.ptlsolar.com/India/Energy-Scenario.asp [ accessed on 20.12.2014]

[2] Source:www.cea.nic.in/reports/monthly/dpd_div_rep/village_electrification.pdf

[3] http://www.unescap.org/esd/environment/lcgg/documents/roadmap/case_study_fact_sheets/Fact 0Sheets/FS- Hybrid-energy-system\%20.pdf [ accessed on 20.07.2014]

[4] http://www.mnre.gov.in/schemes/offgrid/remote-village-electrification [accessed 6.08.2014]

[5] “World Energy Outlook,” International Energy Agencies, pp.303-338, 2010.

[6] Dr. Recayi Pecen, Dr. MD Salim, \& Dr. Marc Timmerman 'A hybrid solar-wind power generation system as an industrial resource for industrial technology'- Journal of Industrial Technology • Volume 16, Number 3 • May 2000 to July 2000.

[7] India Wind Energy Outlook 2012 [accessed 24.01.2013]

[8] http://www.ushdev.com/windmill power activities _. [accessed 6.08.2013]

[9] Bashir, M. ; Ferdowsi Univ. of Mashhad, Mashhad, Iran ; Sadeh, J. 'Size Optimization of New Hybrid Standalone Renewable Energy System Considering a Reliability Index - Environment and Electrical Engineering (EEEIC), 2012 11th International Conference on 18-25 May 2012

[10] http://www.cea.nic.in/reports/articles/god/renewable_energy.pdf [accessed 6.01.2013]

[11] Renewable global status report- 2013 [accessed 6.11.2014] 
[12] www.worldenergyoutlook.org/media/WEO2014_Renewables.pdf ～[ accessed on 20.11.2014]

[13] http://www.ptlsolar.com/India/Energy-Scenario.asp [ accessed on 20.12.2014]

[14] Z. Benhachani, B. Azoui, R. Abdessemed, M. Chabane -“ Optimal sizing of a Solar-Wind Hybrid System Supplying a farm in a semi-arid region of Algeria" - Universities Power Engineering Conference (UPEC), 2012 47th International.

[15] Suresh, P.V.; Sudhakar, K. -"Life cycle cost assessment of solar-wind- biomass hybrid energy system" for energy centre, MANIT, Bhopal, International Conference on Green Computing, Communication and Conservation of Energy (ICGCE), 2013.

[16] Muhamad, M.I, Radzi, M.A.M. ; Abd Wahab, N.I. ; Hizam, H. ' Optimal design of hybrid renewable energy system based on solar and biomass", published in Innovative Smart Grid Technologies - Asia (ISGT Asia), 2014 IEEE.

[17] Bashir, M.; Ferdowsi Univ. of Mashhad, Mashhad, Iran ; Sadeh, J.-Size Optimization of New Hybrid Stand- alone Renewable Energy System Considering a Reliability Index- Environment and Electrical Engineering (EEEIC), 2012 11th International Conference on 18-25 May 2012.

[18] By Dr. Recayi Pecen, Dr. MD Salim, \& Dr. Marc Timmerman 'A hybrid solar-wind power generation system as an industrial resource for industrial technology'- Journal of Industrial Technology • Volume 16, Number 3 $\bullet$ May 2000 to July 2000.

[19] By Lipsa Priyadarshanee -Thesis on "MODELING AND CONTROL OF HYBRID AC/DC MICRO GRID” submitted in Department of Electrical Engineering National Institute of Technology Rourkela769008

[20] Parita Dalwadi, V. Shrinet, C. R. Mehta and Pankit Shah- "Optimization of solar-wind hybrid system for distribution generation”- Engineering (NUiCONE), 2011 Nirma University International Conference on 8-10 Dec. 2011 in Ahmedabad, Gujarat

[21] Razak, N.A.b.A.; Fac. of Electr. Eng., Univ. Teknol. MARA, Shah Alam, Malaysia ; bin Othman, M.M. ; Musirin, I.- " Optimal Sizing and Operation Strategy of Hybrid Renewable Energy System Using HOMER"- Power Engineering and Optimization Conference (PEOCO), $20104^{\text {th }}$ International, 23-24 June 2010

[22] Kalirasu, Subharensu Sekar Dash -“Simulation of Closed Loop Controlled Boost Converter for Solar Installation Athimulam" - SERBIAN JOURNAL OF ELECTRICAL ENGINEERING Vol. 7,No. 1, May 2010, 121-130

[23] M. Bashir, J. Sadeh - "Optimal Sizing of Hybrid Wind/Photovoltaic/Battery Considering the Uncertainty of Wind and Photovoltaic Power Using Monte Carlo- Environment and Electrical Engineering (EEEIC), 2012 11th International Conference on 18-25 May 2012

[24] http://en.wikipedia.org/wiki/History_of_wind_power [ accessed on 20.09.2015]

[25] Kalirasu, Subharensu Sekar Dash - "Simulation of Closed Loop Controlled Boost Converter for Solar Installation Athimulam" - SERBIAN JOURNAL OF ELECTRICAL ENGINEERING Vol. 7,No. 1, May 2010, 121-130

[26] Energy Information Administration (EIA). 2008. Renewable energy trends 2007. Washington,DC. Online athttp://www.eia.doe.gov/cneaf/solar.renewables/page/trends/rentrends.html

[27] 'Life cycle cost assessment of solar-wind-biomass hybrid energy system' for energy centre, MANIT Bhopal, Suresh, P.V.; Sudhakar, K. Green Computing, Communication and Conservation of Energy (ICGCE), 2013 International Conference.

[28] Forest Guild. 2008. Woody biomass removal case studies. Santa Fe, NM. Available online at:http://biomass.forestguild.org/ -[ accessed on 25.10.2015]

[29] Brockaway, Dale., et al. 2005. Restoration of long leaf pine ecosystems. US Forest Service, Southern Forest Research Station. Asheville, NC. Available online at:http://www.srs.fs.usda.gov/pubs/gtr/gtr_srs083.pdf [ accessed on 20.11.2015] 